\title{
Tectono-Metamorphic Deformation and Structures of Mubi-Hong Area, NE, Nigeria
}

\author{
S. N. Yusuf ${ }^{1 *}$, A. Y. Kuku², Y. Ibrahim ${ }^{2}$, S. Kasidi ${ }^{3}$ \\ ${ }^{1}$ Department of Geology, University of Jos, Jos, Plateau State, Nigeria. \\ ${ }^{2}$ Department of Geology, University of Maiduguri, Maiduguri, Borno State, Nigeria. \\ ${ }^{3}$ Adamawa State University, Mubi, Adamawa State, Nigeria.
}

ABSTRACT: The Mubi-Hong area constitutes part of the northeast basement complex of Nigeria and has experienced tectono-metamorphic deformation distinguished into D1, D2 and D3 events. The resultant effect is production of varied ductile and brittle structures (faults, folds, mineral stretching and foliation) which trends mostly in NNW-SSE direction, with other components NNE-SSW and NE-SW. Deformation and metamorphism in the area can be described as being progressive as indicated by the varied nature of synclinal-anticlinal folds. The tensile tectonism is also responsible for the structures and subsequent emplacement of large volumes of granitoids during Pan-African $(600+150 \mathrm{Ma})$. A Multi directional orientation of brittle, planar and linear structures in the area suggests that the area have undergone polyphase deformation similar to those in other parts of the Nigerian basement complex.

KEYWORDS: Tectono-metamorphic, Structures, Deformation, Ductile, Brittle, Basement complex.

[Received July 04, 2018; Revised May 07, 2019; Accepted July 06, 2019]

Print ISSN: 0189-9546 | Online ISSN: 2437-2110

\section{INTRODUCTION}

Mubi-Hong area forms part of the northeast basement complex and comprises of metamorphic (migmatitic gneisses, amphibolites, mylonites) and igneous (intrusive granitoids and volcanics) rocks. The study area also covers parts of Hawal Massif and Adamawa Massif, which together with the Oban Massif constitute the eastern sector of the Nigerian Basement Complex. The study area is located within part of sheet 155 (Garkida) and sheet 156 (Uba) with a scale of 1:100,000 covering an area of about $7,200 \mathrm{Km}^{2}$. It is located within Longitudes $12^{\circ} 50^{\prime} \mathrm{E}$ to $13^{\circ} 25^{\prime} \mathrm{E}$ and Latitudes $10^{\circ} 00^{\prime} \mathrm{N}$ to $10^{\circ} 30^{\prime} \mathrm{N}$ (Fig.1).

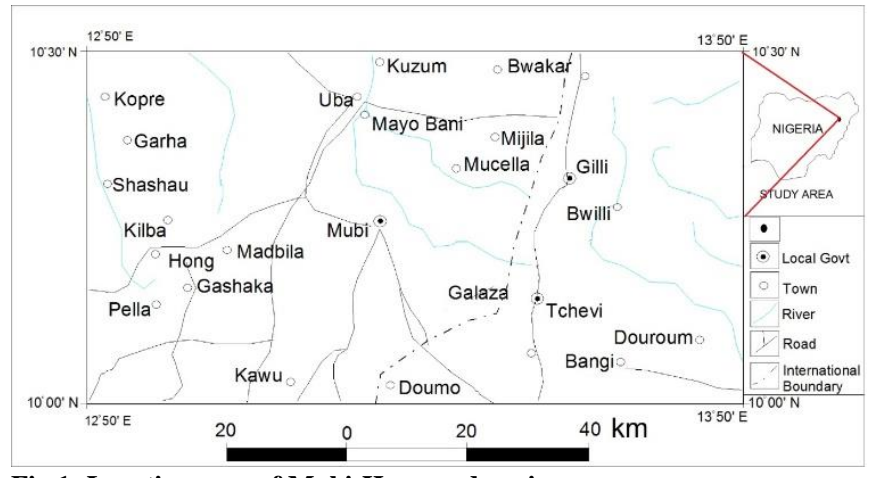

Fig.1: Lacation map of Mubi-Hong and environs.

The drainage pattern in the area is typically dendritic and characteristic of igneous-metamorphic terrains with streams emanating from areas of high relief and draining into low relief areas. The presence of major roads and foot paths makes the area quite accessible except in the hilly areas around Mubi, *Corresponding author: solomonjanjaro@gmail.com
Maiha. Hong and Uba. Islam et al. 1986 differentiated the undifferentiated northeastern Nigerian basement rocks into major and minor types based on study of aerial photographs, field and laboratory studies while Islam et al. (1989) mapped and divided the northeastern Nigerian basement complex (including the Mubi-Hong area) into four; the Mandara Mountain, the Alantika Mountain, the Shebshi Mountain and the Adamawa Massif.

Toteu (1990) investigated the geochemical characters of the main petrographical and structural units of northern Cameroun and assessed its implication for Pan African evolution. The occurrence, field relationships and petrography of different rock types have been described on a regional scale by some workers (Carter et al., 1963 and Mc Curry, 1971). The study of the rocks of Mandara Hills have been made by Islam and Baba (1990), Baba et al. (2006) and Siddig (2012), where they documented the petrogenesis and geochemistry of rocks from Gwoza and Madagali areas (located at the northern tip of the study area). Also, Abaa and Najime (2006) studied the occurrences of some ore minerals such as cassiterite, wolframite, galena, chalcopyrite, barite and gem minerals in the Oban-Obudu-Mandara-Gwoza area in the eastern part of the Nigerian Basement complex.

The Mubi-Hong area like most basement terrains in Nigeria have experienced extensive tectonism and metamorphism leaving behind imprints, structures and the emplacement of large volumes of granitoid in the Pan-African $(600 \pm 150 \mathrm{Ma})$ but because of lack of enough geologic data in the area these events were not adequately documented. This work is aimed at studying the litho-structures in Mubi-Hong area from field and aeromagnetic data and thus constrains the tectono-metamorphic deformations in the area.

doi: http://dx.doi.org/10.4314/njtd.v16i4.7 


\section{REGIONAL GEOLOGY AND STRUCTURES}

The Nigeria Basement Complex forms part of the PanAfrican mobile belt and lies between the West African Craton and the Congo Craton and south of the Tuareg shield (McCurry, 1976; Black, 1980). The region is part of the Upper Proterozoic-Lower Phanerozoic Pan African (600 $\pm 150 \mathrm{Ma})$ mobile belt. The rocks are divided into 3 groups by several workers (Ajibade, 1976, McCurry. 1976; Holt, 1982; Woakes and Bafor, 1984 and Ajibade and Woakes, 1989)

These groups include the following;

i.) The poly-metamorphic migmatite-gneiss-quartzite complex with ages ranging from Achaean to Pan African. The Pan African ages reflect the over printing of widespread and intensive Pan African Orogeny. Rocks of this group are largely migmatites and gneisses, basic schist, relict metasedimentary, calcareous, quartzitic and granulitic rocks.

ii.) Low grade, sediment dominated schist belts trending north-south. These belts are considered to be Upper Proterozoic (Kibaran to Pan-African) super crustal rocks that been folded into the migmatite-gneiss- quartzite Complex. This group consists dominantly of schists, phyllites and banded iron formation. Other rocks include meta-conglomerates, calcareous rocks and metavolcanics.

iii.) Syn to post-tectonic rocks of the Older Granite suite, which intruded both the migmatite-gneiss-quartzite complex and the schist belts. Their ages range from 750 - $450 \mathrm{Ma}$. This group consists dominantly of granites, granodiorites and tonalities. Other minor bodies include gabbros, dolerite, charnokites, syenites, aplites, rhyodacite and rhyolites.

The rocks in Mubi-Hong area comprises of metamorphic (amphibolites, migmatitic gneisses and mylonites), plutonic igneous rocks (diorite, granodiorite, granites of varied textures, aplites and pegmatites) and volcanic igneous rocks (basalts and rhyolites) as presented in Fig. 14. The coarse grained granites constitutes over $60 \%$ of the entire study area while the porphyritic granite constitute about $15 \%$, followed by migmatitic gneisses which make up about $10 \%$ of the area. Granodiorite, volcanics, aplitic and pegmatitic dykes make up the remaining $15 \%$ of the area. Diorite and granite porphyry do not constitute mappable units.

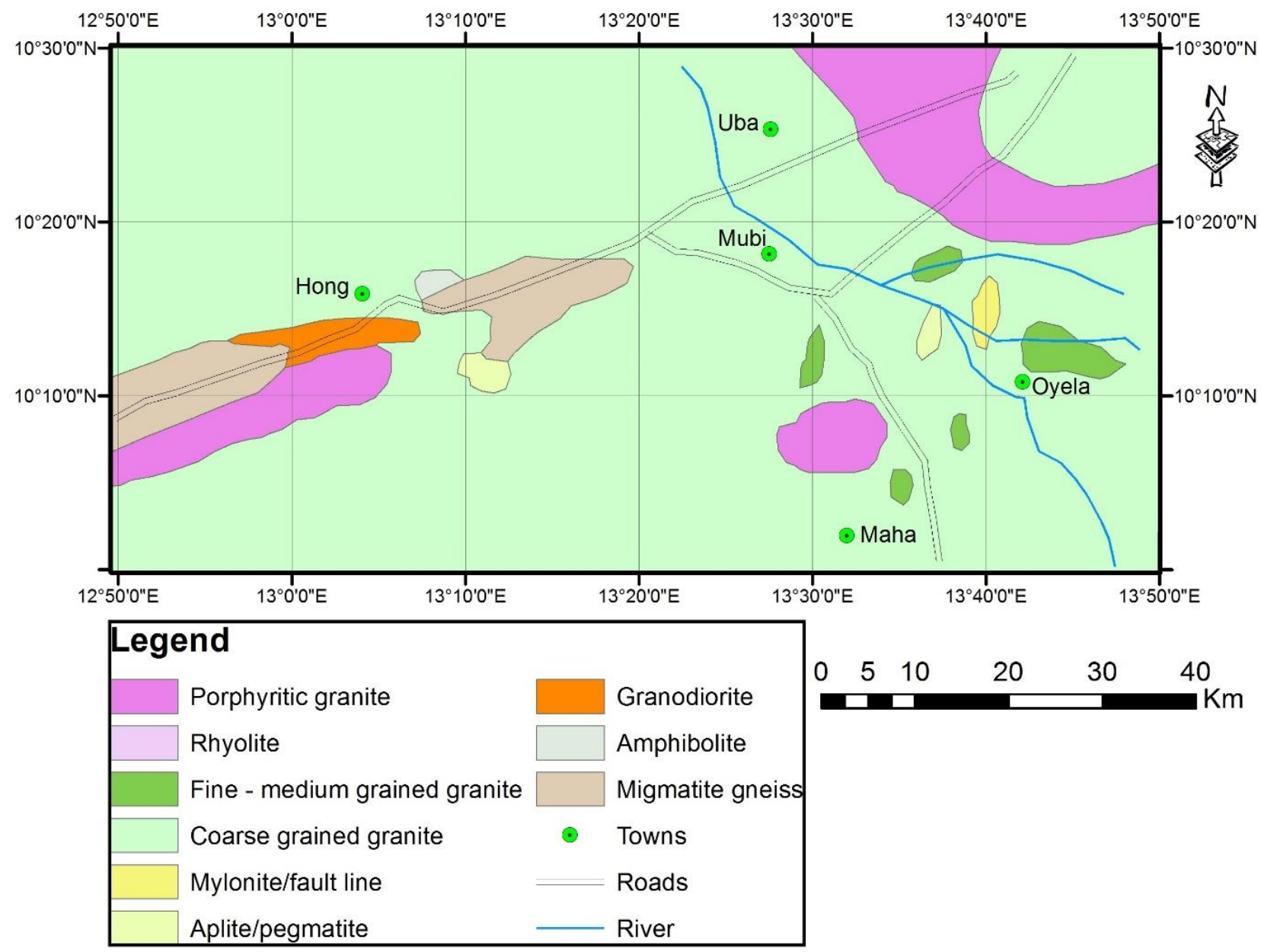

Fig.2: Geological map of the study area. 
The basement complex of Nigeria has undergone a complex evolutionary history involving at least four tectonic events (McCurry, 1971; Rahaman, 1976; Grant, 1978; Musa, 1987; Ajibade and Fitches, 1988; Ogezi, 1988; Ajibade and Woakes, 1989 and Ekwueme, 1990). The events are Liberian $(2800 \pm 200 \mathrm{Ma})$, Eburnean $(2000 \pm 200 \mathrm{Ma})$, Kibaran (1100 $\pm 200 \mathrm{Ma})$ and Pan-African $(600 \pm 150 \mathrm{Ma})$. Several generations of foliations, folds and fractures characterized the Basement Complex of Nigeria. Some of these are clearly shown on a regional scale (Oluyide, 1988). The principal fracture directions of the Nigerian basement complex are in the N-S, NNE-SSW, NNW-SSE and NW-SE and to a lesser extent E-W (Oluyide, 1988 and Olugbenga, 2008).

\section{MATERIALS AND METHODS}

Structural mapping involving identification and mapping of structural features such as fractures, fold, lineation, mineral stretching and foliation was carried out with the aim of producing structural map and rose diagrams for the area. Areas where there is no cohesion in the rocks and which have no relative movements were mapped as joints while infilled joints mapped as veins. The relationship of these joints whether parallel or tangential to each other was noted. The dimensions of the veins were also measured and noted in the

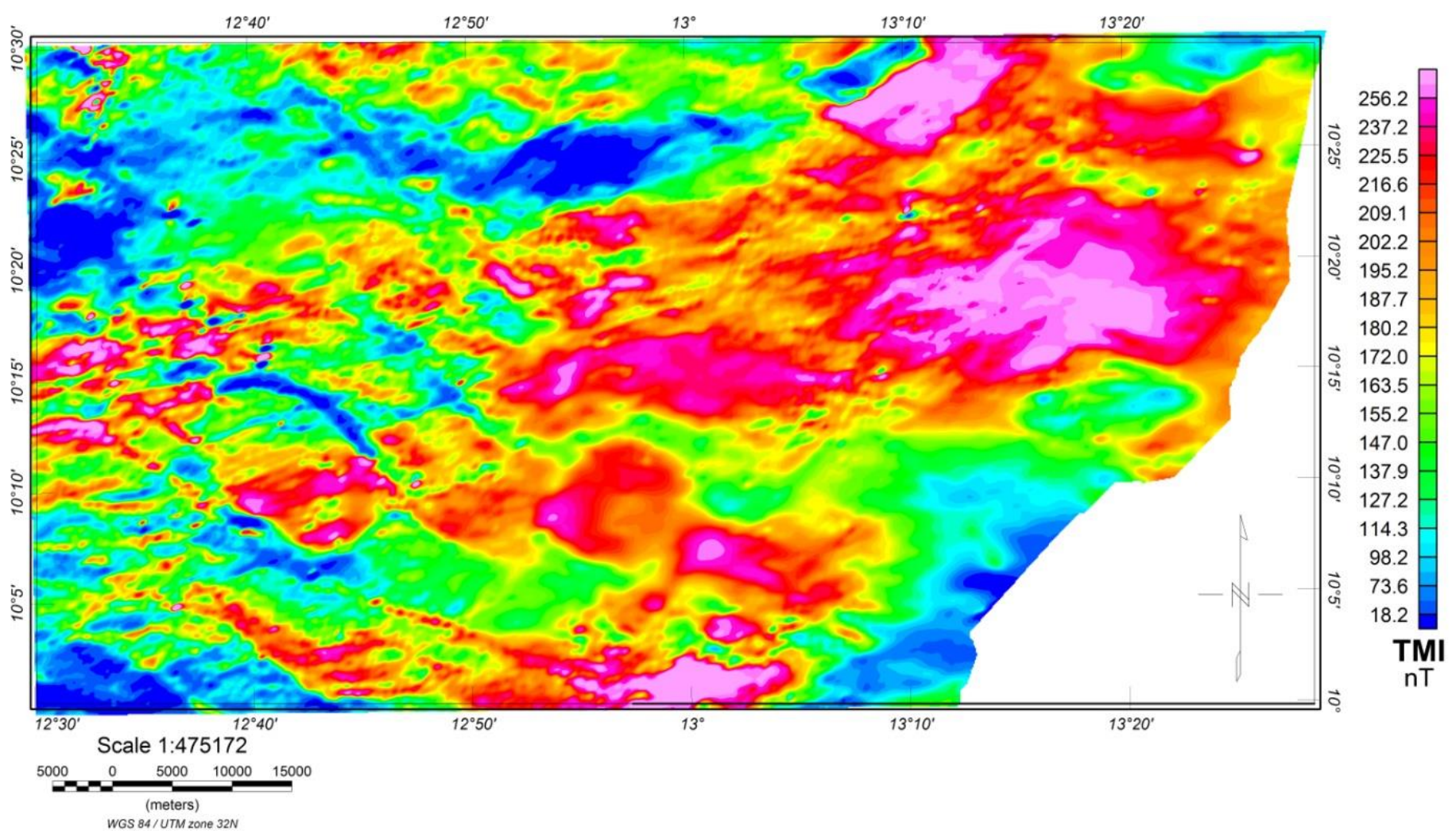

Fig. 3: Total Magnetic Intensity map of Mubi-Hong area. field notebook. Fold geometry and characteristic features were also observed and recorded, while relevant measurement in terms of plunge were also taken. Data obtained from field measurements were presented in Table 1 and then used in the construction of rose diagrams.

The structural map obtained from field structural measurements was then compared with a lineament map produced from aeromagnetic data obtained from the Geophysical unit of the Nigerian Geological Survey Agency, Abuja. The total magnetic intensity field of aeromagnetic data at first did not give much meaning and until when regionalresidual was perform using first polynomial order. Oasis Montaj 8.2 geophysical software was used to obtain the relevant lineament map in the study area. The initial data obtained, referred to as Total Magnetic Intensity (TMI) map (Fig. 3) consists of both residual and regional components that relates to shallow and deeper magnetic sources respectively. A lineament map was then produced using the Centre for Exploration Target (CET) plug-in techniques on the residual data (Fig. 4). Angular measurements were then carried out using ruler and protractor and values obtained plotted to obtain a rose diagram. 


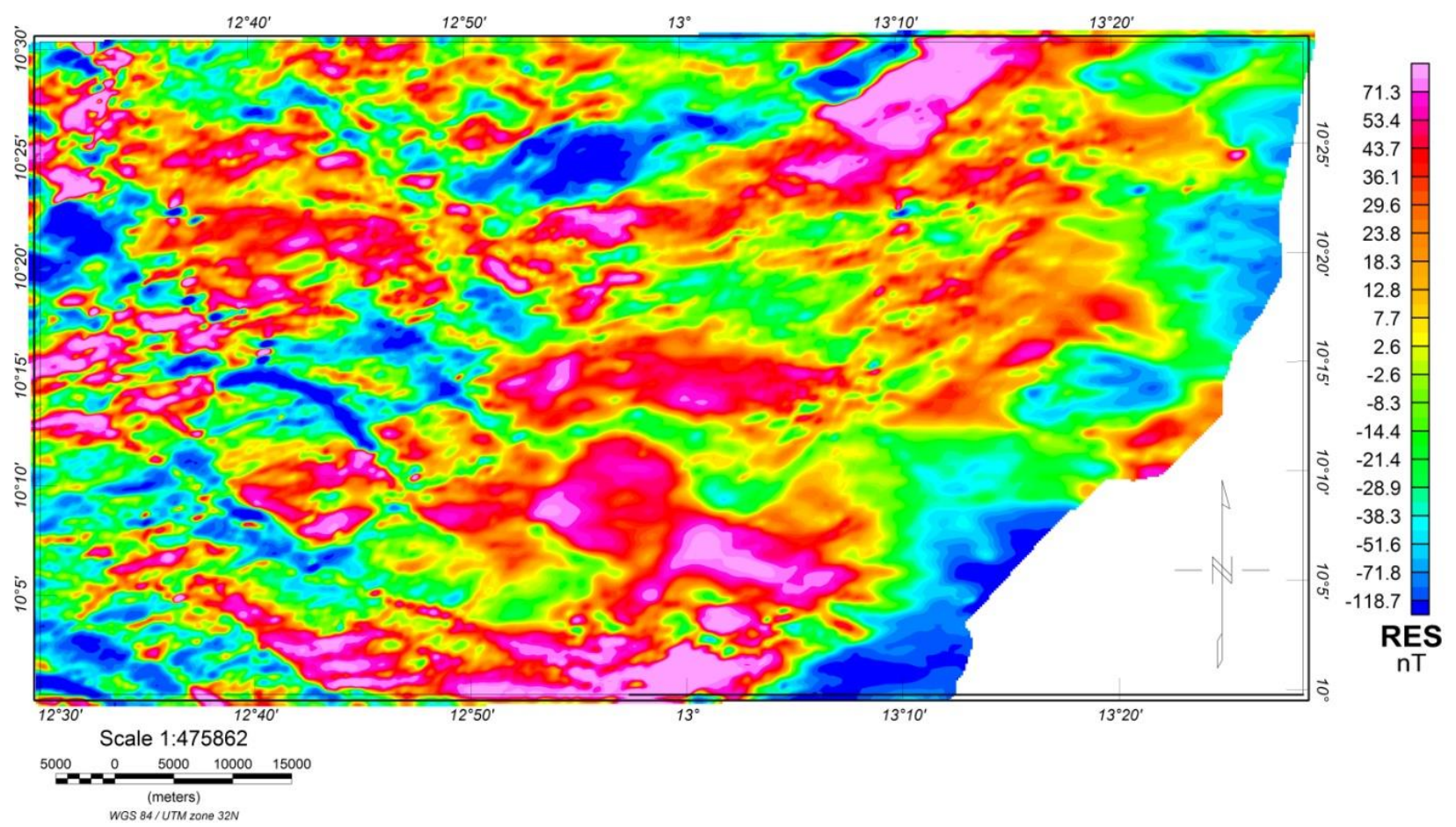

Fig.4: Residual magnetic intensity map of Mubi-Hong area.

\section{RESULTS AND DISCUSSION}

Field relationship of rocks and structural study reveals that the Mubi-Hong area has undergone tectonometamorphic deformations resulting in varied lithostructures and emplacement of large volumes of granitoids and volcanics. Three tectono-metamorphic deformations have been identified in this study,

The first deformation (D1) episode appears regional in extent, which affected pre-existing rocks and responsible for formation of foliations in migmatite gneisses and of planar dimensionally oriented minerals. This event resulted in recrystallization and segregation of minerals under conditions of elevated temperatures and pressures leading to formation of ductile structures typically foliation as melanosome and leucosome bands in migmatite gneisses. The second deformation (D2) event which is also regional in extent appears more intensive and has resulted from metamorphic ductile and brittle deformation of the migmatite gneisses in the area. The result is the formation of distinct structures typified by faults and folds (anticlines and synclines) due to transposition and folding of earlier D1 structures. Common example of this is the straight-edged river which passes at the northern tip of Uba town and valleys which extends for several kilometers and run through the entire study area. The third deformation (D3) event is localized and restricted mainly to the granitoids. This tectono-metamorphic event is driven by pressure and movement along fault zones resulting in shearing and/or grinding of the granitic and pegmatitic rocks into mineral stretching and powdery components that are easily susceptible to degradation and weathering. The rocks are pegmatitic i.e quartzrich, resulted from silicification a typical of the one at Vimtim Village, where it appeared as highly silicified, steeply dipping quartzitic ridge with the feldspartic component having been degraded. Deformation is so intense, especially at the central portion of the fault zone, crushing and grinding of the initial granitic rock into powdery substances that is highly susceptible to weathering, thus forming a valley-like depression as identified some few meters off Mubi Bridge on the Old Mubi-Bazza road (Fig.1 and 2). The third tectono-metamorphic event has not been observed in older rocks such as the migmatite gneisses and so thought to be a later event.

Main litho-structures identified in this study have been distinguished into ductile-plastic structures (foliations, folds, mineral stretching) and brittle structures (fault, joints, quartzofeldspartic veins). Results of field structural measurements were used in plotting rose diagrams while structural map presented as Fig. 5. 


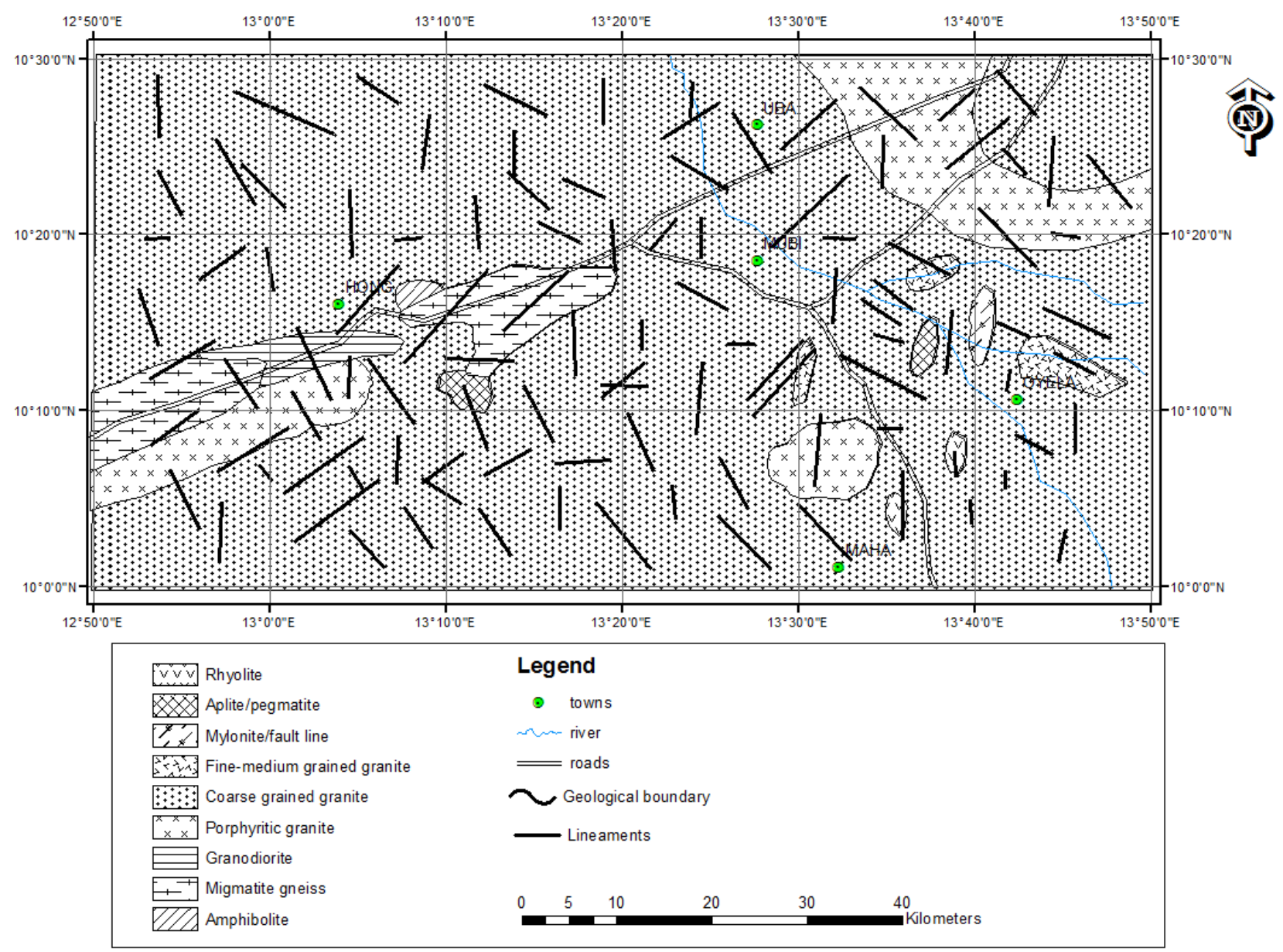

Fig. 5: Litho-Structural Map of Mubi-Hong area.

\section{A. Ductile and Plastic Structures}

Ductile and planar structures are those which results from ductile deformation and parallel alignment or preferred orientation and elongation of minerals without attendant break in the cohesion or continuity of the rocks. These include foliation, mineral lineation/mineral stretching and folds.

\section{1.) Foliations}

Foliations are restricted specifically to migmatitic gneisses and occur as mineralogical banding typified by mafic (melanosome) and a felsic (leucosome) minerals. They are a result of planar arrangement of dimensionally oriented minerals formed by the recrystallization and segregation of minerals growing under conditions of elevated pressures and shearing stress. These foliations are characterized by altitude and orientation (Plate 1) and marked by development of single or two generation of foliation (S1 \& S2).The main structural trend of the foliations is the NNE-SSW but minor trends include the NE-SW, ENE-WSW, NWSE and the WNW-ESE (Fig. 6).

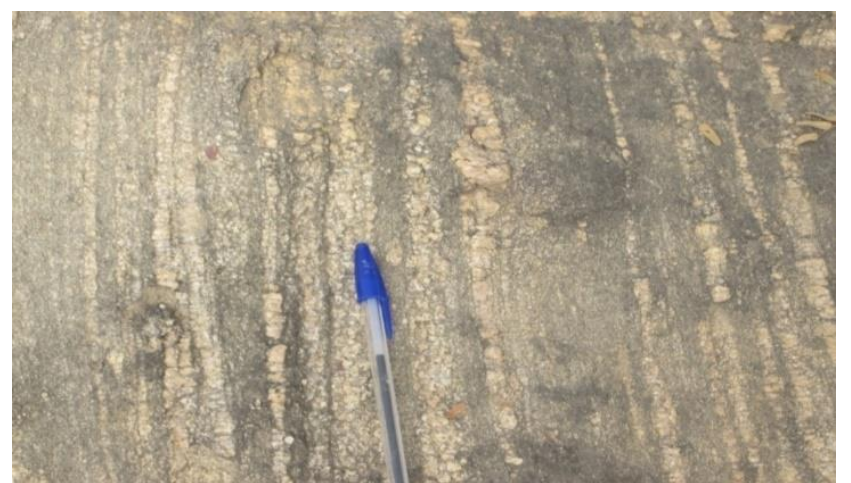

Plate 1: Migmatitic gneiss showing foliation resulting from D1 deformation event $\left(\mathbf{N 1 0}^{\circ} 12.742^{\prime}-\mathbf{E}^{\circ} 3^{\circ} 22.772^{\prime}\right)$. 


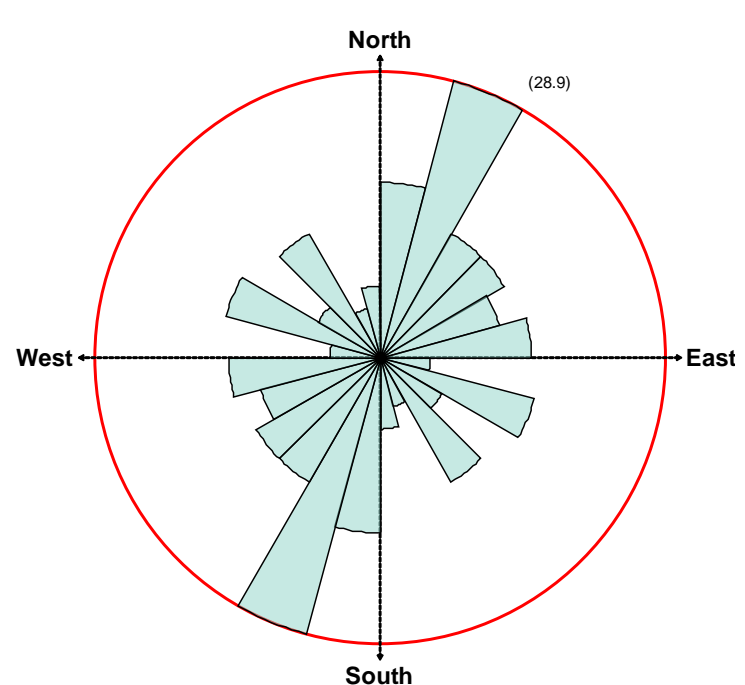

Fig. 6: Rose plot of main foliation trends in migmatite gneiss of Mubi-Hong area.

\section{2.) Mineral lineation and mineral stretching}

Mineral lineation and mineral stretching are marked by parallel alignment or preferred orientation of minerals which undergo ductile deformation thus increasing the lengths of the minerals so affected and thus aligned in a direction tangential to the direction of the applied stress (Plate 2). These are exemplified by the mylonites and to some extent the migmatite gneisses. In the mylonites, mineral stretching is restricted mostly to periphery of the fault zone where crushing of the mineral grains is minimal with plastic deformation becoming dominant. Minerals most affected include ferromagnesian minerals such as hornblende and biotite and to a lesser extent felsic minerals typified by feldspars (Plate 2). The general trend of mineral lineation and stretching in these rocks is mostly the NNE-SSW (Fig. 7), a trend that is in conformity with the trend of the fault.

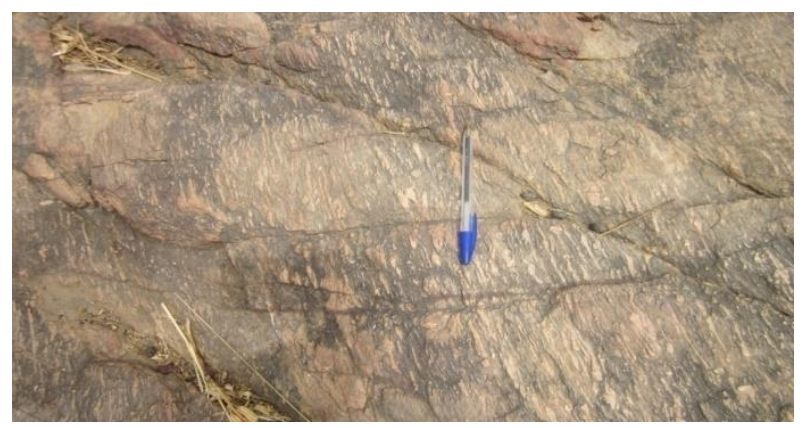

Plate 2: Mineral stretching in mylonites in a direction perpendicular to applied stress (Note that the biro is placed relative to the north direction) $\left(\mathrm{N10}^{\circ} 16.604^{\prime}-\mathrm{E}^{\circ} 3^{\circ} 19.912^{\prime}\right)$.

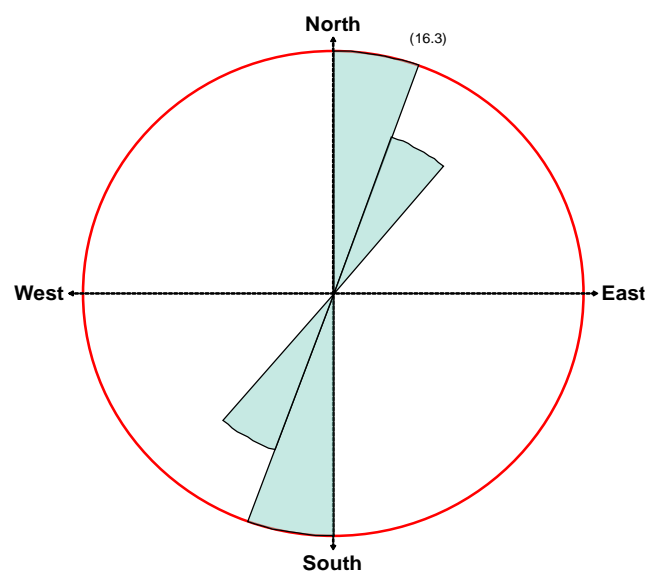

Fig. 7: Rose plot of main trend in mineral stretching and mineral lineation of Mubi-Hong area.

\section{3.) Folds}

These are characterized by synfolds and antifolds, restricted mainly to the gneissose component of the migmatite gneisses (Plates 3, 4, 5 \& 6) especially around Fadaman Reke, Hong area to the southwest and also around Pakka area to the south of the mapped area (Fig. 2). They occur as minor structures and vary in their morphology and architecture from symmetrical to assymetrical, open folds, S-shaped folds and sometimes $\mathrm{M}$ or Zshaped folds (plate 6).

Because of the varied nature of deformation imposed on the rocks, open, tight or closed folds are common in the study area. Plate 4). At least two generations of folds have been constrained in the area. The first generation of fold (F1) appears as open and asymmetrical while the second (F2) folds are tight and mostly symmetrical (Plates 4 ). The two fold types could be related to the intensity of deformation the rocks were subjected to, varying from F1 to F2 producing open and tight folds in the former and later respectively. Generally, the fold plunges trends NNE-SSW direction (Fig. 8) with minor components in the NW-SE, WNWESE, NE-SW, NNW-SSE and ENE-WSW direction. In most circumstances, the folds consist of leucocratic (felsic) minerals at the center with biotite and hornblende forming the lenticular melanosome (mafic) component which were subsequently plastically deformed.

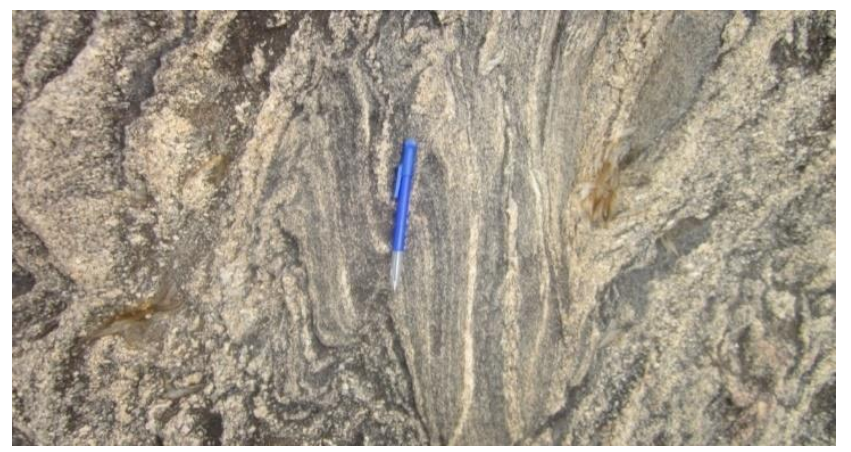

Plate 3: Symetrical (F2) folds in the gneiss of Fadaman Reke, Hong area $\left(\mathrm{N10}^{\circ} 13.759^{\prime}-\mathrm{E12}^{\circ} 58.942 '\right)$. 


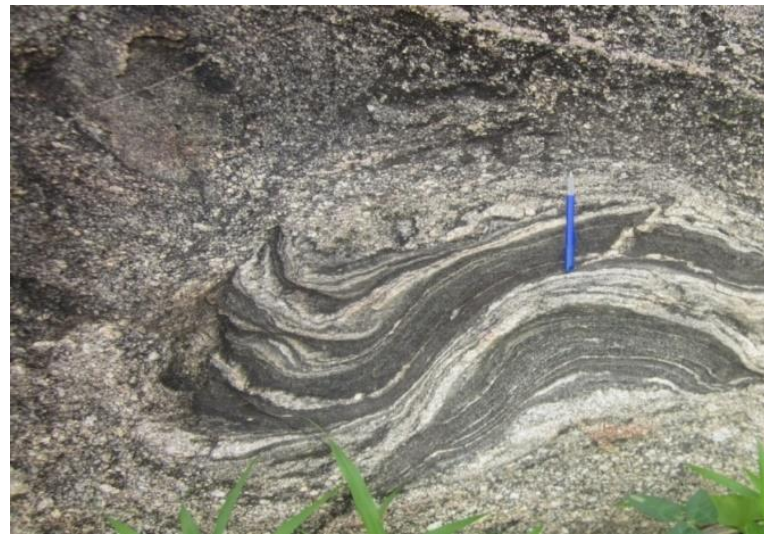

Plate 4: Assymetrical (F1) folds typified by synclines and anticlines in the gneiss of Hong area $\left(\mathrm{N10}^{\circ} 13.759^{\prime}\right.$ E12 $^{\circ}$ 58.942').

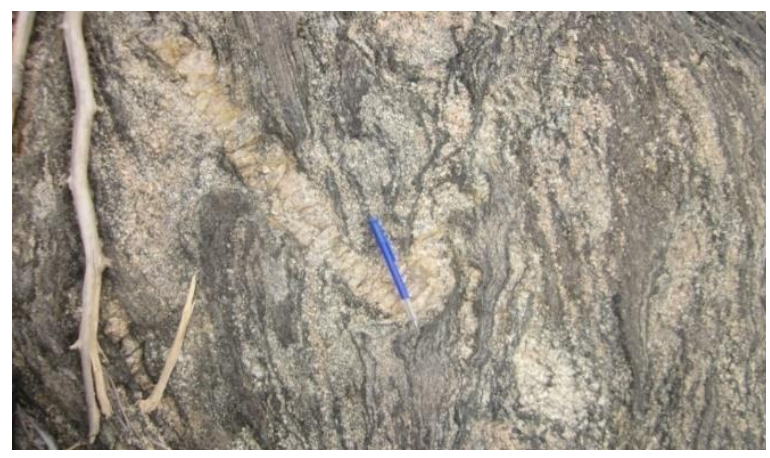

Plate 5:Assymetrical (F1) synclinal folds in the gneiss of Fadaman Reke ,Hong area( $\mathrm{N10}^{\circ} 13.915^{\prime}$ - E12 $\left.{ }^{\circ} 59.311^{\prime}\right)$.

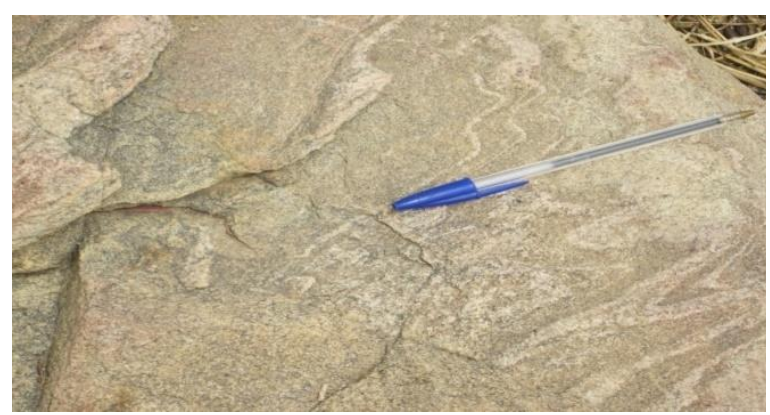

Plate 6: Typical S-shaped and M-shaped folds in the migmatite gneisses around Old Cameroun Road, Mubi area $\left(\mathrm{N}^{\circ}{ }^{\circ} 12.409^{\prime}\right.$ - $\left.\mathrm{E}^{\circ} 3^{\circ} 19.920^{\prime}\right)$.

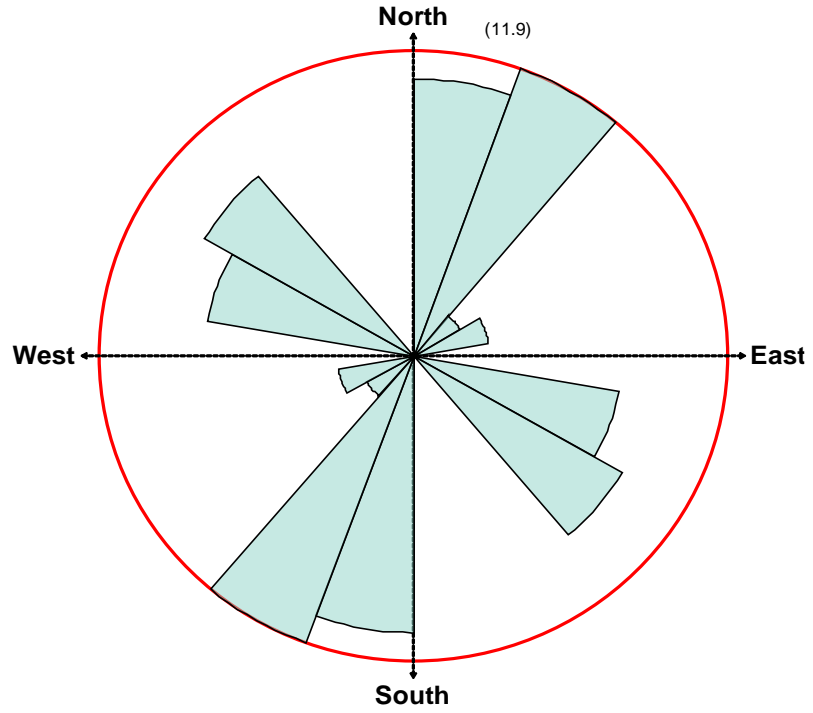

Fig. 8: Rose plot showing the trends of Fold plunges in the rocks of Mubi- Hong area.

\section{B. Brittle Structures}

These include structures formed from brittle deformation that subsequently resulted in the failure of the rocks and therefore a loss in cohesion and continuity of the outcrop results. They are generally termed fractures and include joints, quartzo-feldspartic veins and faults. (Plates 7,8, \& 9).

\section{1.) Quartzo-Feldspartic veins}

These occur as infillings within existing fractures in the rocks. They are widespread in the area but more dominant in the granitoids differing in intensity and orientation and cross cutting each other (Plate 7). In most outcrops these crosscutting relationships help in identifying and determining order of formation of at least two to three generations of the veins. Generally the infillings are constituted of quartz and feldspars and often pegmatitic. The veins vary in thickness from a millimeter to few centimeters but could extend for several tens of meters in extent and are mostly inclined vertically in relation to the host rocks. The general trends of the quartzo-feldspartic veins are the NNE-SSW, other minor trends are NE-SW, NNW-SSE, ENEWSW and the WNW-ESE orientations (Fig. 9).

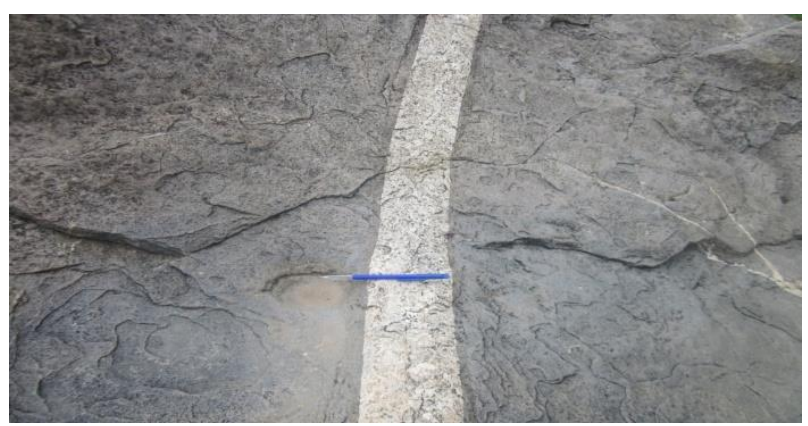

Plate7: Field photograph of quartzo-feldsparthic veins cross-cutting the main granitoid body $\left({\mathrm{N} 10^{\circ} 14.796^{\prime}-\mathrm{E}^{\circ} 3^{\circ} 19.192}^{\prime}\right)$. 


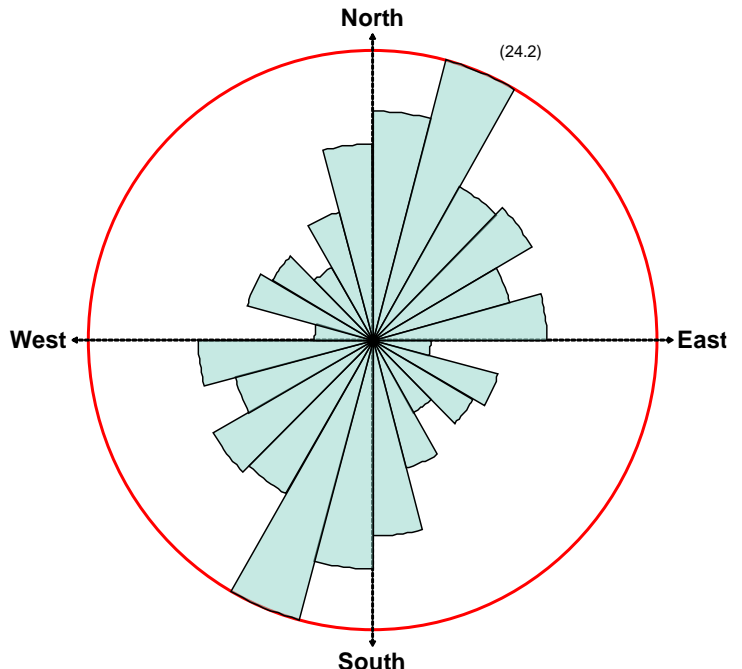

Fig. 9: Rose plot showing trends of quartzo-feldspartic veins in rocks of Mubi-Hong area.

\section{2.) Joints}

Joints occur almost invariably in all rock types in the study area, the dominant, being in granitoids in the area. They are shown in this study to cross-cut each other, with no defined orientation (Fig. 10). The spacing in the rocks which resulted from the jointing, ranges from a few millimeters to few centimeters and occur either as near vertical steeply dipping or horizontal structures. Though joints trend in all directions, the major structural trend is the NNE-SSW (Fig. 10). Other notable trend include the NE-SW, NNW-SSE, WNW-ESE, NW-SE and to some extent the ENE-WSW directions.

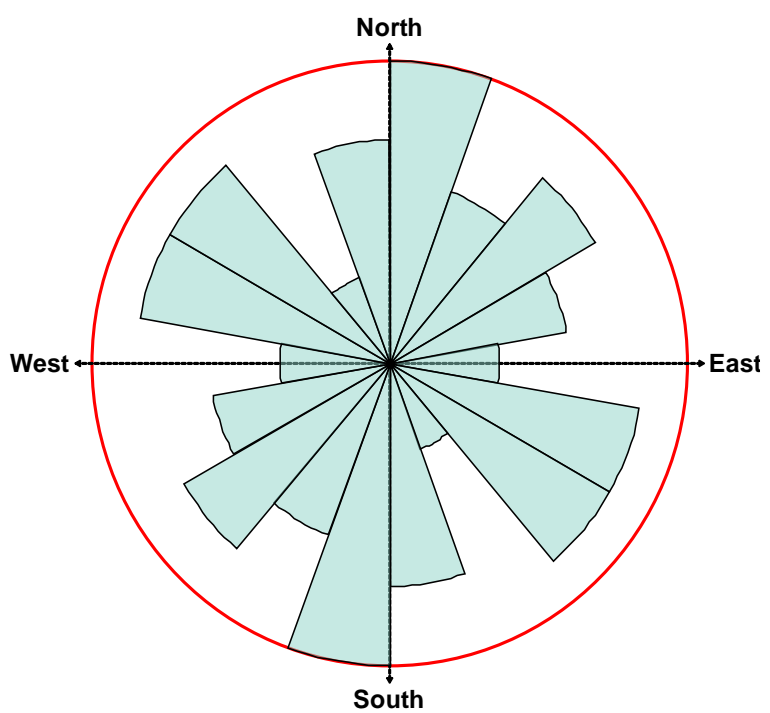

Fig. 10: Rose plot of multi-directional trends of joints in rocks of Mubi-Hong area.

\section{3.) Faults}

Two types of faults namely the major faults (mapped from the field and extracted from aeromagnetic map) and minor faults (mapped in the field) were identified in this study. A quartzitic/pegmatitic ridge around Vimtim village, a mylonitic ridge before the Mubi bridge at the central portion of area of study and also around Pakka (plate 8) to the south of the study area are all characteristics of fault. Along these ridges, the granitoids have been intensely sheared, striated and faulted. The quartzitic ridge in Vimtim was identified as a major fault and runs for several kilometers in north-southerly direction.

This was also identified from the aeromagnetic lineament map of the area. Several straight edged rivers (Pakka, Lamorde, and Yedzaram) and valleys in the area were also identified as faults both in field and from lineament map of the area. The faults in this area trend mostly NNW-SSE with minor trends in the NNE-SSW direction (Fig.11). Major lineaments identified from aeromagnetic map of the area are in conformity with the trend of faults observed in the field. Typical amongst which is the NNW-SSE lineament which corresponds with the trends obtained in the field.

Minor faults marked by small displacements (Plate 9) of the order of few centimeters to few meters were encountered mostly in the migmatite gneisses and to some extent in the granitoids especially the coarse grained types. These are the normal faults which are sinistrally or dextrally displaced.

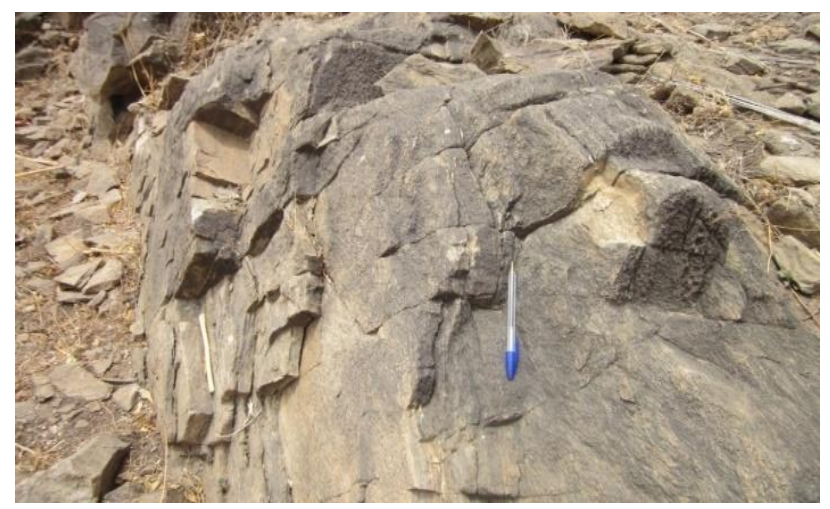

Plate 8: Mylonitized ridge marking a fault zone off Mubi-Bazza road $\left(\mathrm{N10}^{\circ} 16.604^{\prime}-\mathrm{E}^{\circ}{ }^{\circ} 19.912^{\prime}\right)$.

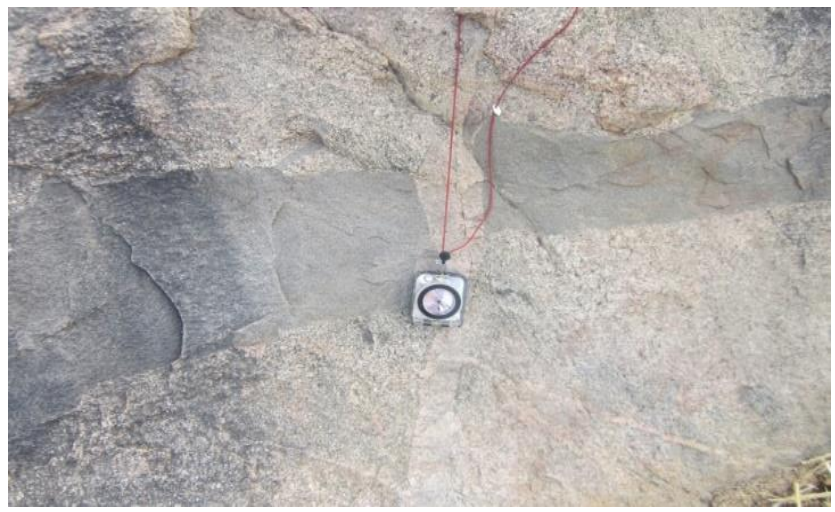

Plate 9: Minor dextral fault in granitoids near Customs check point, Mubi $\left(\mathrm{N10}^{\circ} 14 . \mathrm{796}^{\prime}\right.$-E13 $\left.^{\circ} 19.192 '\right)$. 


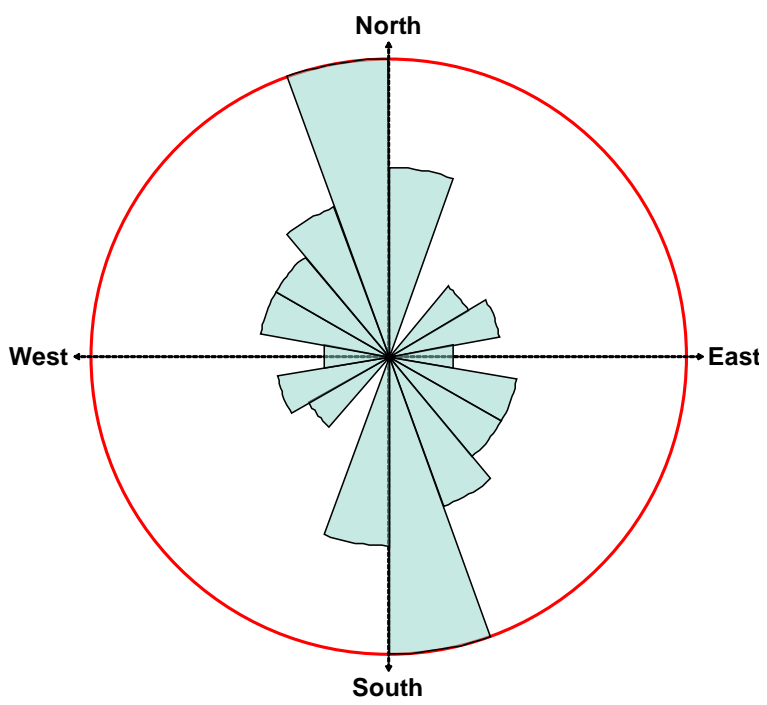

\section{Lineaments Extracted from Residual Magnetic Intensity Map}

The total magnetic intensity map (Fig. 3) comprises of both deep and surficial features (with values ranging from 18.2 to 256.2 nT). The residual magnetic Intensity map (Fig. 4) of Mubi-Hong area gave values ranging from -118.7 to $71.3 \mathrm{nT}$ while the lineament map (Fig.12) produced from the residual Intensity map of the area indicates that the main structural trend is the NE-SW (Fig. 13) with minor components in the NNE-SSW, ENE-WSW, and NNW-SSE and to lesser extent the E-W trend. The results further shows that the structures measures between less than 2 kilometers to over 10 kilometers in extent with the later being constrained as major faults. These trends are comparable to those obtained from field measurements and to those obtained by Bassey et al, (2006) in parts of the northeastern sector of the Nigerian basement complex.

Fig. 11: Rose plot showing the main trend of faults in Mubi-Hong area.

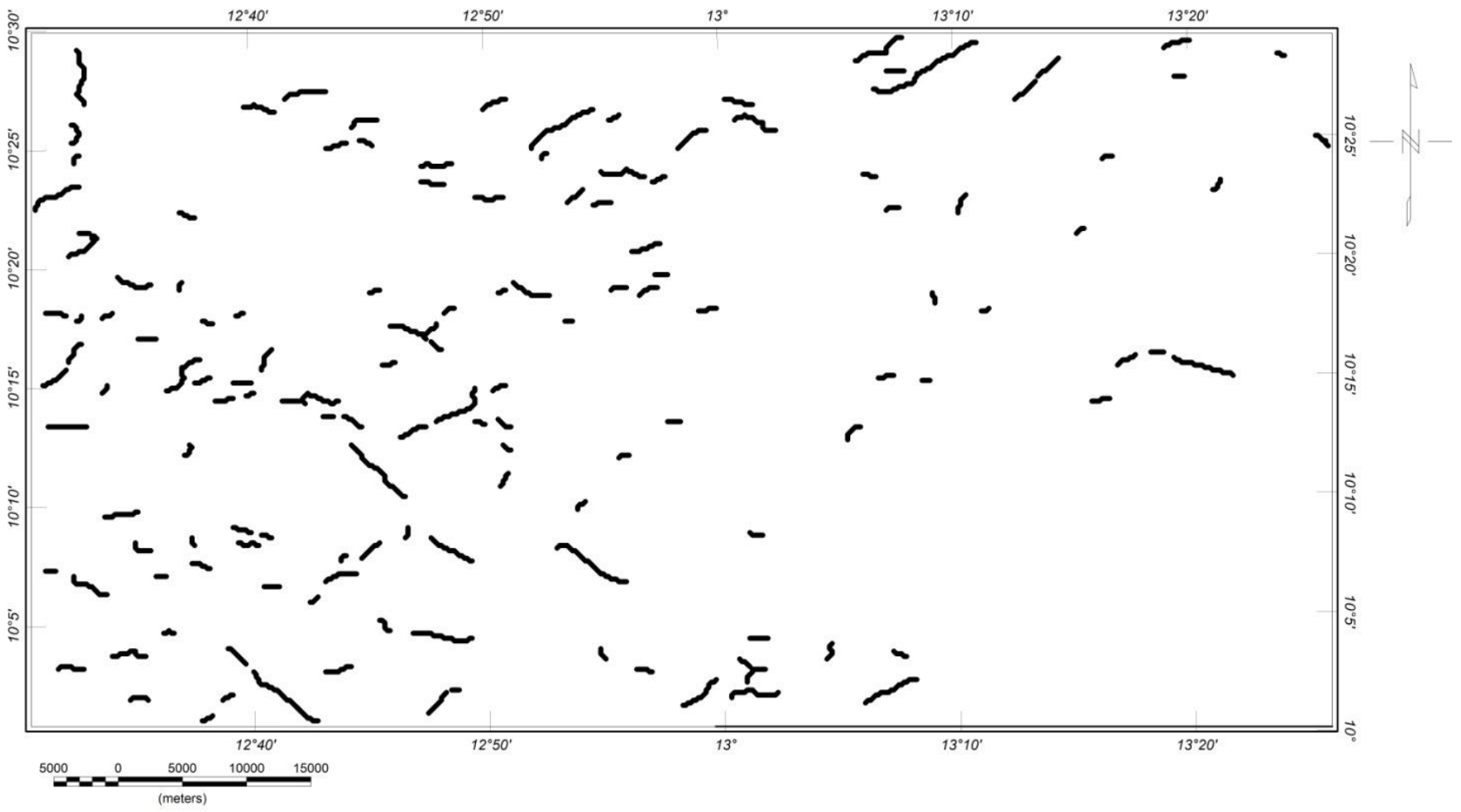

Fig. 12: Lineament map produced from residual magnetic density map (10 above) of Mubi -Hong area. 


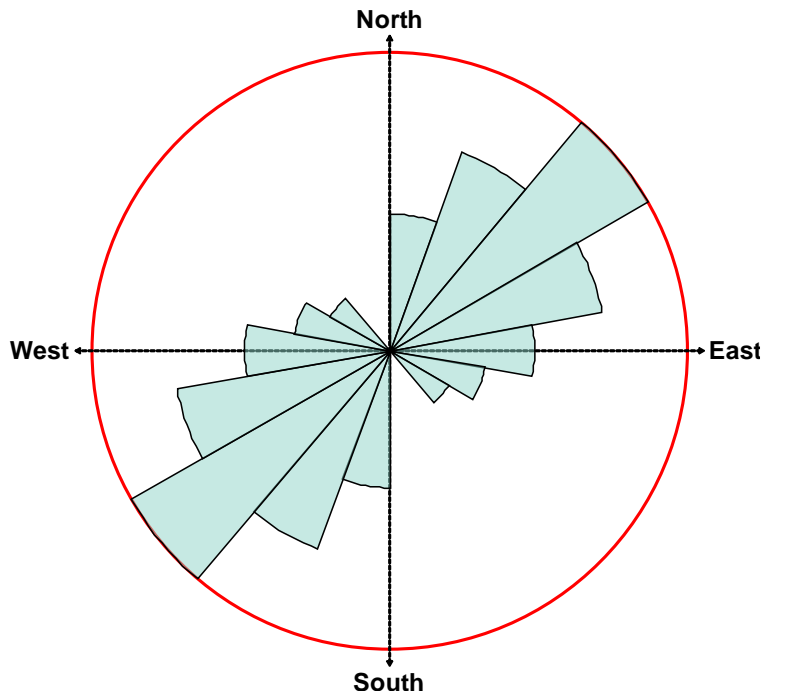

Fig. 13: Rose plot of lineament extracted from residual map of MubiHong area.

\section{Volcanic plugs}

Volcanic plugs in the area were observed to host rhyolitic, basaltic and sometimes pyroclastic rocks in zones of structural weaknesses. The main trend of these plugs is the NNW-SSE while others includes the NNE-SSW and NESW components (Fig.13). These trends are compatible with major structural trends obtained in the area especially those of faults and also comparable to the main structural grain of the Nigerian basement complex.

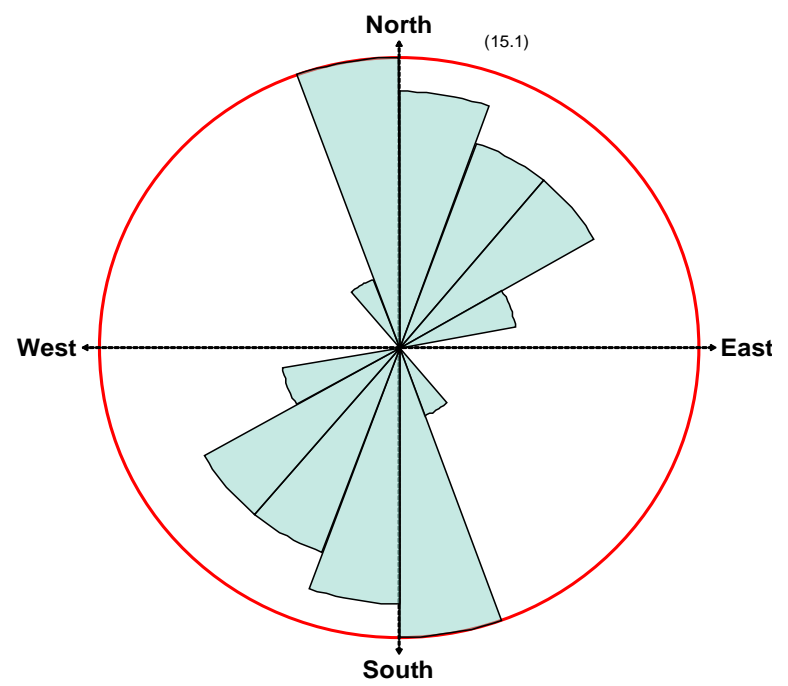

Fig. 14: Rose plot for trend of volcanic plugs in Mubi-Hong area.

Contact relationships and mode of occurrence shows that the amphibolites and migmatitic gneisses in the area are the oldest rock units, having been intruded by the granitoids. Dynamic metamorphism and mylonitization were restricted mainly to the granitoids and so thought to be a later event. Furthermore, the intrusion of the granitoids into the dioritic and granodioritic rocks in the area suggests that they are younger while the intrusion of pegmatitic/aplitic rocks marks the end of emplacement of the intrusives in the area. The emplacement of the granitoids have been structurally controlled possibly after the first tectonic deformation (D1) event in the area possibly along D2 structures such as faults while restriction of mylonites to the granitic rocks shows that they were emplaced at a later period as a result of the D3 deformation and metamorphism.

The main structural trends in the rocks are comparable and suggestive of similarity in their evolution. An exception to this was shown by joints which have no peculiar structural trends thus attributable to cooling and contraction of magma at the time of emplacement. A Multi directional orientation of brittle, planar and linear structures in the area suggests that the area may have undergone polyphase deformation similar to those in other parts of the Nigerian basement complex. At least three of such deformations (D1, D2 and D3) have been identified in the area producing varied structures including foliation, folds, faults and joints with multi-directional orientations of NNW-SSE,NNE-SSW and NE-SW,

Field and aeromagnetic structural patterns obtained in this study appear comparable, with trends mostly in NNW-SSE with others trending in NNE-SSW and NE-SW, thus similar to the main structural grain in the Nigerian basement complex (Oluyide, 1988; Bassey et al. 2006. The emplacement of volcanics in the area was structurally controlled within structures created on the early formed rocks especially the granitoids. The similarity in trends of volcanic plugs of the area to those in granitoids attests to this and could mean that the volcanics were emplaced at a later stage after the emplacement of the granitoids but within similar structures. Deformation and metamorphism in the area can be described as being progressive as evidenced from the varied nature of synclinal-anticlinal folds typical amongst which are the Stype, M-type, Z-type folds. Similarly, the restriction of ductile structures in some and brittle structures in others point to the fact tectono-metamorphic deformation in the area is progressive and varies in intensity.

Tectonic differentiation and metamorphic segregation may have been the dominant processes that led to the development of foliations in the rocks of Mubi-Hong area, a view earlier proposed by Ajibade (1988) and Ekwueme (1990) for rocks of southeast basement complex. The dominantly NNW-SSE and NNE-SSW trend obtained in the foliation of the area are in agreement and indicative of Pan African orogeny (Egesi and Ukaegbu, 2010).

Conspicuous structures shown by banding and mineral stretching in the rocks of Mubi-Hong area, have been a result of planar arrangement of dimensionally oriented minerals due to recrystallization and segregation of minerals growing under conditions of elevated pressures and shearing stress typically in gneisses and mylonitic rocks respectively, thus comparable to those in rocks of Bansara region of southeastern Nigeria (Egesi and Ukaegbu, 2010). It is also shown that the emplacement of the volcanics in the area is structurally controlled as they trend in a manner similar to structures in the host granitoids and therefore, it is believed that the emplacement of the volcanic is post Pan-African where structures produced as a result of late Pan African deformation were used. 


\section{CONCLUSION}

The Mubi-Hong area has undergone multi-phase tectono-metamorphic deformations identified as D1, D2 and D3. The tectono-metamorphic deformation is progressive and responsible for varied nature of both ductile and brittle structures in the area. The main structural trends in the rocks are comparable and include the NNW-SSE, NNE-SSW and the NE-SW similar to those obtained from the Nigerian basement complex. The emplacement of the granitoids in the area is structurally controlled possibly along D2 structures in the Pan-African $(600 \pm 150 \mathrm{Ma})$. The restriction of mylonitization/deformation to the granites and not in older rocks shows that it is a later event. Structures identified in this study provide suitable sites for ore deposition and so further studies is suggested to confirm the occurrence or otherwise of ore deposits in the area.

\section{ACKNOWLEDGEMENTS}

We acknowledge the management of University of Maiduguri for financial support during fieldwork. Mr. Peter Samaila and Naboth Simon are acknowledged for assisting in fieldwork.

\section{REFERENCES}

Abaa, S.I. and Najime, T. (2006). Mineralization in Precambrian rocks of central Nigeria: Implications for the Oban - Budu - Mandara - Gwoza complex of eastern Nigeria. Global Journal of Geological Sciences, 4 (2): 121 - 128.

Ajibade, A.C. (1976). Provisional classification and correlation of schist belts in NW Nigeria. In: Kogbe C.A. (ed.) Geology of Nigeria. Elizabethan publishing company, Lagos. 85-90.

Ajibade, A.C. (1988). Structural and tectonic evolution of the Nigerian basements with special reference to NW Nigeria. International Conference on Proterozoic Geology and Tectonics of high grade terrains. University of Ile-Ife, Nigeria. $22 \mathrm{p}$.

Ajibade A.C. and Woakes, M. (1989). Proterozoic crustal development in Pan-African regime of Nigeria. In: Kogbe C.A. (ed.), Geology of Nigeria. Second revised edition, Rockview Nigeria Ltd. Jos. 57-69.

Ajibade, A. C. and Fitches, W. R. (1988). The Nigerian Precambrian and Pan-African Orogeny. In: Oluyide, P. O. (coordinator), Precambrian Geology of Nigeria, 45-53

Baba, S.; S. I. Abaa and S. S. Dada. (2006). Preliminary Petrogenetic Study of Some Rocks from Gwoza Area, NE, Nigeria. Global Journal of Geological Science, 4, 2, 147-156.

Bassey, N. E; S. S. Dada and A. A. Omitogun. (2006). Preliminary Structural Study of Satellite Imagery over Basement Rocks of Northeastern Nigeria and Northern Cameroun. Journal of Mining Geology, 42, 73-77.

Black, R. (1980). Precambrian of Nigeria. Episode 4, 3 8.

Carter, J. D.; W. Barber and E. A. Tait. (1963). Geology of parts of Adamawa, Bauchi and Bornu provinces in Northeastern Nigeria. Bulletin geological Survey Nigeria 30, 1-108.
Egesi, N. and Ukaegbu, V. U. (2010). Petrology and Structural Characteristics of the Basement Units of Bansara area, Southeastern, Nigeria. The Pacific Journal of Science and Technology, 11, 1, 510-522.

Ekweume, B. N. (1990). Petrology of Southern Obudu Plateau, Bamenda Massif, Southeastern Nigeria. In: Rocchi, G. and Deschamps, M. (eds.). Recent data in African Earth Sciences. CIFG, Paris, France. 22,155-158.

Grant, N. K. (1978). Structural Distinction between Metasedimentary Cover and Underlying Basement in $600 \mathrm{~m}$. y. old Pan African Domain of Northwestern, Nigeria, West Africa. Geological Society of America bulletin, 89, 50-58.

Holt, R. W. (1982). Geotectonic evolution of Anka belt in the Precambrian basement complex of northwestern Nigeria. Unpublished Ph.D thesis, Open University, Milton Keynes, United Kingdom .320p.

Islam, M. R. and Baba, S. (1990). The mineral potentials of northern part of Mandara Hills, Nigeria. Burg-Und Huttenmanische Manatchefte (BHM), 135, 4, 95-98.

Islam, M. R.; S. Ostaficzuk and S. Baba. (1986). A report on the Geological Studies and Exploration of Industrial Rocks and Minerals in the northern part of Mandara Hills, Nigeria.Annals of Borno, 3, 279-281

Islam, M. R.; S. Ostaficzuk and S. Baba. (1989). The Geology of the Basement Complex of the Northern Part of Mandara hills. Annals of Borno, 6, 7, 99-105.

McCurry, P. (1971). Pan- African Orogeny in Northern Nigeria. Geological Societyof America Bullletin, 82, 3251-3262.

McCurry, P. (1976). The Geology of the Precambrian to Lower Paleozoic Rocks of Northern Nigeria, A review. In; Kogbe, C.A. (ed.), Geology of Nigeria, Elizabethan press, Lagos, 15-39.

Musa, B. S. (1987). Minerals and industry in Nigeria with notes on the history of geological survey in Nigeria. Second edition, published by the authority of the government of the federal republic of Nigeria, 60p.

Ogezi, A.E. (1988). Origin of the basement complex of northwestern Nigeria in the light of new geological data. In: Oluyide, P.O. (coordinator), Precambrian Geology of Nigeria, 300-312.

Olugbenga, O. (2008). Deformation and mineralization in the Basement Complex of Nigeria. In; Proceedings of International Geological Congress, Oslo. August $6^{\text {th }}-14^{\text {th }}, 2008$.

Oluyide, P. O. (1988). Structural trends in the Nigerian basement complex. In: Oluyide, P. O. (coordinator), Precambrian Geology of Nigeria, Geological Survey Nigeria, 93-98.

Rahaman, M. A. (1976). Review of the Basement Geology of Southwestern Nigeria. In: Kogbe, C. A. (ed) Geology of Nigeria. Elizabethan Publishing Company, Lagos, 41 - 58.

Siddig, A. A. A. (2012). Geochemistry of granitoids from Madagali area, Mandara Hills, northeastern Nigeria. Unpublished $\mathrm{Ph}$. D thesis, University of Maiduguri, Nigeria.143p.

Toteu, S. F. (1990). Geochemical Characterization of the Main Petrographical and Structural Units of Northern Cameroon: Implications for Pan-African evolution. Journal of African Earth Sciences, 10, 4, 615-624. 
Woakes, M. and Bafor, B. E. (1984). Primary gold mineralization in Nigeria. In: Foster, R.P. (ed.), Gold 82: The geology, geochemistry and genesis of gold deposits.
Geological Society of Zimbabwe, special publication No.1. Balke - Ema, Rotterdam, 661- 671. 